\title{
Management of Ectopic Pregnancy and the COVID-19 Pandemic
}

\author{
Rujittika Mungmunpuntipantip $^{10}$ Viroj Wiwanitkit ${ }^{1}$ (이 \\ ${ }^{1}$ Ajeenkya DY Patil University, Pune, Maharashtra, India \\ Address for correspondence Rujittika Mungmunpuntipantip, \\ Rev Bras Ginecol Obstet 2021;43(2):148-149. \\ Ajeenkya DY Patil University, Pune 412105, Maharashtra, India \\ (e-mail: rujittika@gmail.com).
}

Dear Editor,

We would like to share ideas on the publication "Medical Treatment for Ectopic Pregnancy during the COVID-19 Pandemic." Elito Júnior and Araujo Júnior ${ }^{1}$ mentioned that the "clinical treatment of ectopic pregnancy by MTX or expectant management is an alternative during the COVID-19 pandemic. An early diagnosis and appropriate selection of treatment options are critical for the success of the treatment." 1 In fact, using methotrexate (MTX) as alternative treatment for ectopic pregnancy during COVID-19 is a useful approach, and can reduce risk as well as decrease the workload at the hospital. The patient selection is very important. However, it should be noted that MTX might cause renal impairment, ${ }^{2}$ and COVID-19 has a trend to develop renal impairment due to the immunopathological process of infection. ${ }^{3}$ Close monitoring of the renal function is needed in MTX therapy, and the adjustment of the dosage based on renal function is important. ${ }^{4}$

Conflict of Interests

The authors have no conflict of interests to declare.

\section{References}

1 Elito Júnior J, Araujo Júnior E. Medical treatment for ectopic pregnancy during the COVID-19 pandemic. Rev Bras Ginecol Obstet. 2020;42(12):849-850. Doi: 10.1055/s-0040-1718438

2 Howard SC, McCormick J, Pui CH, Buddington RK, Harvey RD. Preventing and managing toxicities of high-dose methotrexate. Oncologist. 2016;21(12):1471-1482. Doi: 10.1634/theoncologist.2015-0164

3 Sriwijitalai W, Wiwanitkit V. Coronavirus-antibody immune complex: A nanostructure appraisal possible cause of nephropathology. Saudi J Kidney Dis Transpl. 2020;31(03):694-695. Doi: 10.4103/1319-2442.289457

4 Nunes LLA, Lima TM. Use of medicines for covid-19 treatment in patients with loss of kidney function: a narrative review. J Bras Nefrol. 2020; •*::S0101-28002020005044202. Doi: 10.1590/21758239-JBN-2020-0105 [ahead of print]

\section{Author's response}

\section{Reply to "Management of Ectopic Pregnancy and the COVID-19 Pandemic"}

\author{
Júlio Elito Júnior ${ }^{10}$ Edward Araújo Júnior 1 1이 \\ ${ }^{1}$ Department of Obstetrics, Escola Paulista de Medicina, Universidade \\ Federal de São Paulo, São Paulo, SP, Brazil
}

Address for correspondence Edward Araújo Júnior, Departmento de Obstetrícia, Escola Paulista de Medicina, Universidade Federal de São Paulo, Rua Botucatu 740, Vila Clementino, São Paulo, SP, 04023-062, Brazil (e-mail: araujojred@terra.com.br).
DOI https://doi.org/ 10.1055/s-0041-1725937. ISSN $0100-7203$
(C) 2021. Federação Brasileira de Ginecologia e Obstetrícia. All rights reserved.

This is an open access article published by Thieme under the terms of the Creative Commons Attribution License, permitting unrestricted use, distribution, and reproduction so long as the original work is properly cited. (https://creativecommons.org/licenses/by/4.0/)

Thieme Revinter Publicações Ltda., Rua do Matoso 170, Rio de Janeiro, RJ, CEP 20270-135, Brazil 


\section{Dear Editor,}

Thank you for your comments. The most important message of this letter was the correct selection of patients for the medical treatment with methotrexate (MTX). We mentioned in the third paragraph that one of the exclusion criteria was renal dysfunction. Therefore, before the treatment, blood samples of every patient were collected for some exams, and one of them was creatinine. High levels of creatine were an exclusion criterion for the MTX treatment. On the other hand, patients with normal levels of creatinine can be submitted to the medical treatment. For tubal pregnancies, we recommend a single dose of MTX $\left(50 \mathrm{mg} / \mathrm{m}^{2}\right)$. The risk of renal impairment related to this dose is very rare. ${ }^{1}$
However, close monitoring of the renal function is necessary in cases of non-tubal pregnancies submitted to the protocol of multiple doses of MTX.

\section{Conflict of Interests}

The authors have no conflict of interests to declare.

\section{Reference}

1 Clark LE, Bhagavath B, Wheeler CA, Frishman GN, Carson SA. Role of routine monitoring of liver and renal function during treatment of ectopic pregnancies with single-dose methotrexate protocol. Fertil Steril. 2012;98(01):84-88. Doi: 10.1016/j.fertnstert.2012.03.037 